\title{
THE ARCHAEOLOGICAL ANALYSIS OF MASONRY FOR THE RESTORATION PROJECT IN HBIM
}

\author{
I. Trizio ${ }^{1}$, F. Savini ${ }^{2}$, A. Giannangeli ${ }^{1}$, R. Boccabella ${ }^{3}$, G. Petrucci ${ }^{1}$ \\ ${ }^{1}$ Institute for Construction Technologies, CNR, 67100 L'Aquila, Italy - (ilaria.trizio, Giannangeli, gabriele.petrucci)@itc.cnr.it \\ ${ }^{2}$ Freelance Archaeologist, 67100 L’Aquila, Italy - fransav83@gmail.com \\ ${ }^{3}$ Freelance Architect, 67100 L'Aquila, Italy - roberta.boccabella@libero.it
}

\section{Commission II}

KEY WORDS: Digital Photogrammetry, HBIM, Architectural Heritage Data Management, Archaeological Survey, Stratigraphic Analysis

\begin{abstract}
:
The experience described in this paper concerns a research activity carried out by a multidisciplinary team. The research is aimed to increase the in-depth knowledge of the castle of Fossa (L'Aquila), part of a small fortified medieval village, seriously damaged by the earthquake in 2009, and currently unusable due to partial collapses of some vertical structures, small portions of buildings and roofs. The investigative path planned by the team, composed of archaeologists, architects and engineers, started from the architectural survey (direct and indirect) of the artefact, from the collection and cataloguing of the published and archive documents, to arrive at an archaeological analysis of the structure and the creation of a parametric digital model of the object of the study with multiple levels of information. The aim of the research is the consideration of the asset in its entirety, that will be interpreted in its restoration project, in order to restore the correct and original architectural interpretations of its constructive style. The project has also presented the opportunity to experiment, in the form of a research laboratory, how well coordinated multidisciplinary contributions can achieve objectives of protection, conservation and use of the asset. In this regard, the HBIM model has constituted a tool for the convergence of the objectives, skills and the different viewpoints of the multidisciplinary team.
\end{abstract}

\section{INTRODUCTION}

The earthquake that the in 2009 struck the city of L'Aquila and its territory, the area now called the "seismic crater", profoundly hit the population not only for the victims, but also for the massive damage to the cultural heritage of the city and surrounding area.

Today, in the specific case of post-seismic reconstruction, many of these cultural heritage buildings are being restored. Having to intervene on historical buildings requires an in-depth study of those buildings in order to guarantee a correct recovery of the structure, and also allows the experimentation of new methods and tools aimed at restoration and, subsequently, on the management, maintenance, enhancement and use of the structure.

The area of the seismic crater is characterized by the presence of numerous small historical centers, described as "minor", in reference to their size, in terms of both physical extension and population, and not, in any way, to their historical and cultural value, which is expressed at a number of different scales, from that of individual buildings and then to the broader urban context and wider landscape. The castle analyzed is located in one of these, in fact Fossa is a small municipality a few kilometers from the city of L'Aquila, in the central valley of the Aterno river. Important tools for the coordination of post-seismic reconstruction are the Reconstruction Plans (PdR) that each municipality has been called to draft. The PdR of the Municipality of Fossa (PdR 2012) was drafted by the University of Catania (Prof. C. Carocci) and of Genova (Prof. S. Lagomarsino). This PdR identifies the area of the Castle as a Urban Re-qualification Centre (RU_A) of the Historic Centre leading to the development of some projects (eg Carocci et al. 2015).

The restoration project of the castle of Fossa, integrated in the perspective of redeveloping the whole municipality, presented the opportunity to our team to carry out a scientific project with Figure 1: Panoramic view of the castle of Fossa a strong multidisciplinary value aimed at increasing information to define an optimal intervention strategy for the conservation of the architectural complex.

The castle, in fact, is an architectural complex which was recently listed by the Government Department Responsible for the Environment and Historical Buildings, characterized by a considerable formal and historical complexity (Figure 1): transformed first into a fortified village, then in a noble residence up to the current placing in private houses connected to the village of Fossa.

It is precisely due to the complexity of this case, and the need to find a unique way to integrate the different interventions of the multidisciplinary team members, that the experimentation of BIM technology applied to an historical complex was used.

\section{BACKGROUND}

Accepting that documentation of the historical built heritage is a prerequisite for its knowledge, conservation, use and enhancement, the international scientific community has long sought to use digital 3D models for this purpose, and in particular by the possibility to use the parametric digital modeling (BIM) for this purpose.

In the last ten years, as has emerged from a series of recent literature reviews of this topic (Volk et al., 2014; Logothetis et al., 2015; López et al., 2018; Pocobelli et al., 2018), there is a growing interest in H-BIM, Historic Building Information Modelling, according to a broader meaning than originally defined in 2009 (Murphy et al., 2009), and subsequently enhanced (Dore and Murphy, 2012), mainly linked to the creation of parametric libraries for historical buildings.

What has been highlighted by such reviews is that the workflow to follow for the construction of an H-BIM seems to be sufficiently standardized, from the data acquisition phase, to the semantic planning of the system and at least until the parametric modeling phase. 


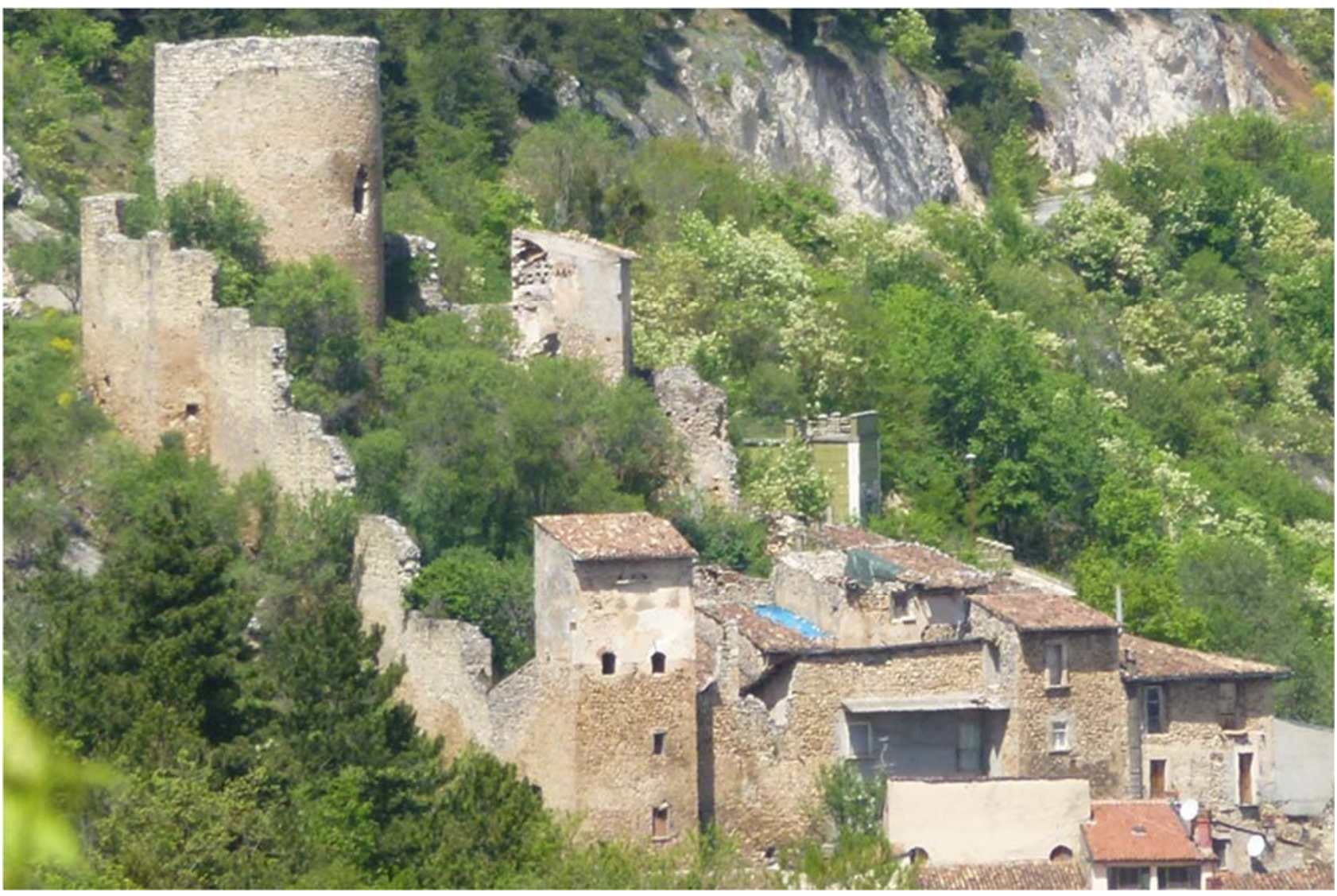

Figure 1: Panoramic view of the castle of Fossa

Most of the contributions analyzed describe the combination of new data acquisition technologies (laser scanning and digital photogrammetry) with BIM platforms starting from "scan-toBIM" procedures, and almost all research groups start from the concept of "as-built BIM", literally intended as documentation of an existing or historical building, then after its construction, or representation of the state of the building at the time of its documentation, sometimes more correctly referred to "as-is" BIM (Dore and Murphy, 2018).

There are also numerous research groups currently involved in automating processes aimed at constructing parametric objects starting from point clouds in BIM. Yet despite the automatic recognition of objects and the detection of features showing promising results in the case of HBIM, and although there are semi-automatic solutions and tools that can improve the efficiency of some phases, it is not yet possible to completely automate the process from point clouds and a lot of work still needs to be done in this area (López et al., 2018).

In general, however, scientific literature is in agreement that the HBIM is a tool that lends itself to the planning and managing of conservation and restoration projects, especially for its ability to interface with multidisciplinary teams, although the lack of algorithms able to completely automate virtual modeling from point clouds, makes parametric component modeling a timeconsuming process (López et al., 2018; Brumana et al., 2018a, Pocobelli et al., 2018).

Some research groups are simultaneously engaged in defining the possibility of integration between Ontology and BIM, which are two tools for the semantic representation of the existing for which Ontology represents the explicit specification of a conceptualization and the BIM the digital representation of the object on which it is possible to geo-refer non-graphic information (Fiorani, 2017; Acierno et al., 2017).
Other groups are on the other hand engaged in research on the most advantageous feature of BIM for heritage science that is represented by its ability to link the 3D models to metadata and therefore all the possible ways of including them within the models (Pocobelli et al., 2018). Finally, it is worth noting that the scientific community is carrying out a thorough reflection on the level of reliability of HBIM models in the correspondence between the model and reality. The debate was developed starting from the analysis of the LOD (Level of Detail) parameter, well known for BIM systems, that represents the graphic detail with which a model or an element of it is graphically represented, to which is associated the Grade and the level of detail of the representation (Lo Turco, 2016). For the HBIMs, the research groups that are working on this, proposed the introduction of a new parameter, the LOR (Level of Reliability), which intends to indicate the level of correspondence between reality and the elements of the model elaborated by the operator by a critical analysis process and, consequently, the degree of knowledge of reality (Nicastro, 2016; Bianchini, Nicastro, 2016). This research has also contributed to enrich the debate, in the specific field of architectural restoration, on the creation of modeling protocols, guidelines, specifications and coding criteria to support HBIM management in the time following its life cycle (Brumana et al. 2018b).

\section{RELATED WORKS}

Amongst the most recent contributions related to HBIM for the management of restoration sites, a significant example that is part of the context of the post-seismic reconstruction of the territory of L'Aquila, is given by the HBIM of the Collemaggio church in L'Aquila (Della Torre, 2017; Brumana et al., 2017; Brumana et al., 2018a; Brumana et al., 2018b). The Basilica, which is among the most representative artefacts of the city, dates back to the XIII 
century and has been the object of many changes over time, and in the earthquake of 2009 was heavily damaged, with the collapse of its dome and transept.

The restoration of the building, which was reopened for worship in December 2017, is the result of teamwork between Eni, the city administration, the Government Department Responsible for the Environment and Historical Buildings and some Italian universities.

Specifically, the HBIM of the Collemaggio church, funded as the entire restoration by EniServizi, was planned by integrating the laser scanner geometric survey with the photogrammetric and direct survey (Brumara et al. 2018a) and, as for the Castello di Fossa, starting from these data and from the historicalarchaeological research, the HBIM of Collemaggio has been set up to support the restoration project through a decision-making process. Although in this case the object of study was a single artefact and not an entire architectural complex such as is the case with the castle of Fossa, the approach used by the research group is quite similar.

To the parametric model of the basilica was required a great interoperability of the elements correlated to different information, a basic requirement to guarantee the management by many actors of different phases (diagnostic analysis, analysis of the finite elements, economic analysis, construction site, cost calculation, restoration) and great precision in the representation of each element from a geometric point of view (Brumara et al., $2018 b$ ). From these two requirements, of combining a reliable representation in the shapes and contents, arose the two new concepts of "Grade of Generation" (GOG) and "Grade of Information" (GOI), related to the modeling of the objects, adapting the LOD logic of the AIA specifications (AIA, 2015), designed for the BIM of new buildings, to the specific case of the restoration of the architectural heritage (Brumana et al., 2018b). Other similarities between these two studies can also be found in the management of thematic maps in BIM, integrated into the parametric model of Collemaggio to manage three-dimensionally the analysis of the materials and the analysis of the degradation starting from the orthophotos of the masonry surfaces, used in the HBIM of Fossa in order to represent and manage the analysis of the deterioration of the masonry and the stratigraphic units derived from the archaeological analysis of the masonries analyzed.

Among the most evident results of Collemaggio's HBIM there is certainly the reflection, acknowledged by the UNI standard 11337-4-2017 regarding the codification criterion in the domain of "Restoration" processes. The proposed coding, on the LOD scale for restoration, intervenes specifically on the LOD F and G, considering the LODs from $\mathrm{A}$ to $\mathrm{E}$ as not significant to the restoration interventions (UNI 11337-4-2017). The new LODs require explicitly a detailed geometric description of all the components of the building (F), taking into account their uniqueness, the state of the art, the obligatory process of material documentation and decay, together with the updating of interventions (G) (Brumana et al., 2018b).

Although our research group has been involved from some time in testing parametric modeling for the archaeological analysis of historical architecture (Continenza et al., 2018; Brusaporci et al., 2018) and restoration sites (Trizio et al., 2017), the HBIM of the Basilica of Collemaggio represented a fundamental guide for the application to the castle of Fossa, albeit with different variations due to the complexity of the case study, above all for the implications of that experience in the normative field.

Finally, regarding the manual modeling procedure adopted starting from the point cloud, the approach is the one followed by many other research groups (Brumana et al., 2018a; López et al., 2017; Scianna et al., 2018) who use proprietary software Revit Autodesk and the more classic procedures based on the creation of "generic models" and the modification of existing parametric families.

\section{THE ARCHAEOLOGICAL ANALYSIS OF THE CASTLE OF FOSSA}

In Italy integration between archeology and restoration started with the stratigraphic revolution of the 70 s (Brogiolo and Cagnana, 2012) and was consolidated with the foundation, in 1996, of the "Archeologia dell'Architettura" review, which became an important multidisciplinary comparison table. In the articulated situation of the post-seismic reconstruction of the L'Aquila territory unfortunately it is not always possible to put this combination into practice. In fact, probably due to the bureaucratic, social and economic complexity that characterizes the earthquake crater of 2009 , the basic knowledge needed to commence a restoration project is often reduced to a historical analysis that is not always sufficient. But in this context there are also conscious professional figures, often supported by private sponsors, who undertake more detailed studies of historic buildings, which acknowledges that a more in-depth knowledge of cultural heritage is a fundamental prerequisite of a restoration project. It is precisely in this way that the castle of Fossa was analyzed, for which, in parallel to the architectural investigations, the analysis of the deterioration and the cracking, the structural analysis and energy efficiency, historical analysis were undertaken together with the archaeological ones, that adopting the well-established methods of the archeology of architecture and integrating the tools with the modern techniques of detection, management and use of the data.

Fossa has very ancient origins as confirmed by the presence of the Italic settlement of Mount Cerro (Mattiocco, 1989; Bourdin, 2006), by the necropolis (Cosentino, D'Ercole and Mieli, 20012003) and the remains of the ancient city of Aveja, identified in the XVIII century (Giovenazzi, 1773).

The castle of Fossa rises as the summit of the village and is placed, like many others in the territory of L'Aquila, on a mountain ridge; it is characterized by walls with towers that, inside a trapezoidal perimeter, enclose several buildings mostly of which are residential.

The only part of the complex that still shows defensive features is the circular tower, it is public property, object of restoration work carried out in the eighties. It is located in the upper part of the settlement which, according to many scholars, constitutes a pre-existence to the wall circuit (Perogalli, 1975; Chiarizia and Properzi 1995; Chiarizia, Latini and Properzi, 2002; Santangelo, 2002).

The documentary sources relating to the castle of Fossa are few: the castle is mentioned for the first time in the Bull of Pope Alessandro III in 1178 between the possessions of the Bishop of Forcona and, later, in the Innocenzo III Bull in 1204 (Martella and Medin, 1988). Subsequently the castle was annexed to the Barony of Ocre, which passed under the dominion of Carlo I d'Angiò in 1266. Probably the circular tower dates to this first phase but this is a hypothesis difficult to confirm in the absence of specific archaeological investigations. The presence of the hamlet, from which the current one developed, is recorded in the XIV century by the "Statuta Civitatis Aquile" (Clementi, 1977, pp. 168-170). During the Middle Ages, the castle, like the neighbouring ones, underwent several sieges and in modern times handed around by the Spaniards, who governed the territory of L'Aquila in the XV century, then to be passed on to several owners until nowadays.

Private ownership of the buildings of the Castle, has ensured continuity of its use and constant fruition until the earthquake of 2009, and contributed to the conservation not only of the architecture, but also of historical terraces used as vegetable 
gardens, almond groves and fences for the rearing of domestic animals.

The castle of Fossa is made up of a set of architectural complexes and each one consists of several buildings. The entire monumental complex, with the stratifications that have transformed it over time, is characterized by a set of buildings with different typologies and construction techniques that increase the problems faced in the restoration project. Moreover, as the documentary sources relating to the Castle are few, the artefact was considered the main source, through the archaeological analysis aimed at the stratigraphic reading of the walls. For this reason, analyses were carried out aimed at classifying the types of masonry, abacus were designed of the architectural elements (portals, windows, niches), damage and the historical anti-seismic protections were recorded, identifying the different stratigraphic masonry units (USM) and the relative stratigraphic relations, indicating the most ancient portions and the modern superfetations.

The masonries identified have been grouped into eight types, some of which show variations that contributed to subdivision into sub-types. Most of the masonries are made of stone material of calcareous origin, irregularly rough-cut with direct percussion instruments, bound by abundant mortar and arranged in sub-

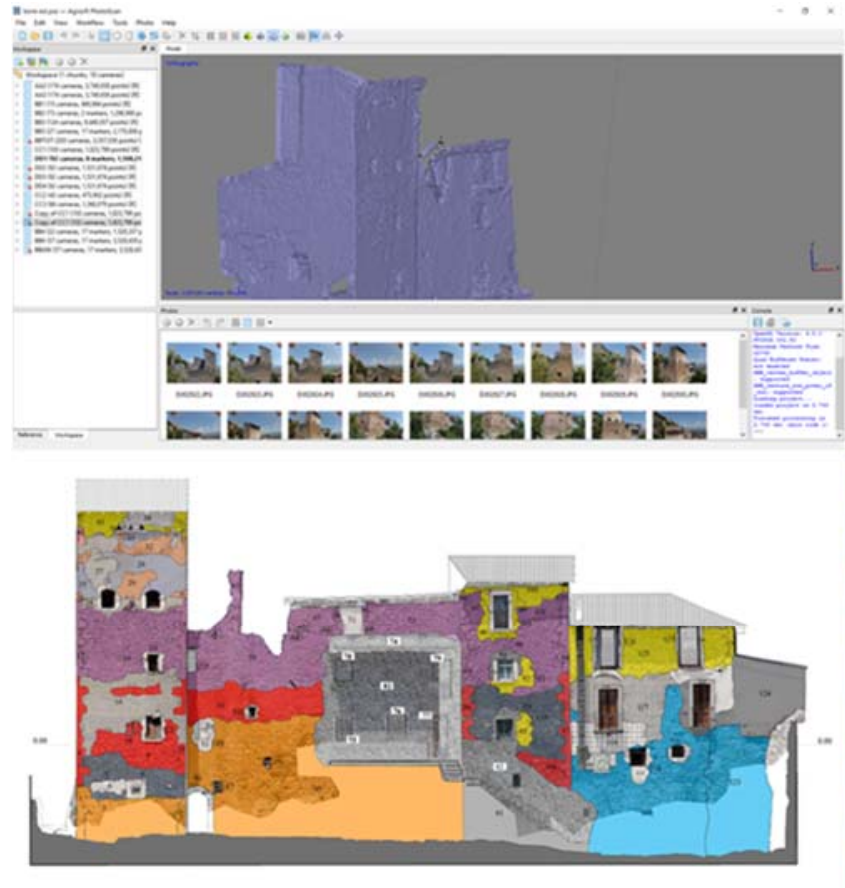

horizontal courses with particular attention to the installation of the angular stones of the external walls. The chronologically more recent types are more irregular and have fragments of bricks used as wedges to fill the empty spaces between the stones. Weak points of the walls are represented by the modern superfetations mostly in concrete.

In conclusion, the buildings analysed have good quality masonries thanks to the materials and construction techniques used, characteristics that have allowed the conservation of the artefact until today.

The particular condition of the buildings studied, seriously damaged and not yet made safe, conditioned the methodology of the investigation. In situ campaigns were conducted aimed at acquiring photographic material for the survey of the artefact. The stratigraphic analysis of the masonries was carried out both on the photoplanes of the fronts, generated by the photogrammetric model, and on the digital model by software for displaying and editing the meshes, considering the volume of the stratigraphic units. Furthermore, together with the archaeological information an immersive model of the castle has been created, aimed at disseminating and enhancing the asset; a model that can also be used by non-professionals (Figure 2).

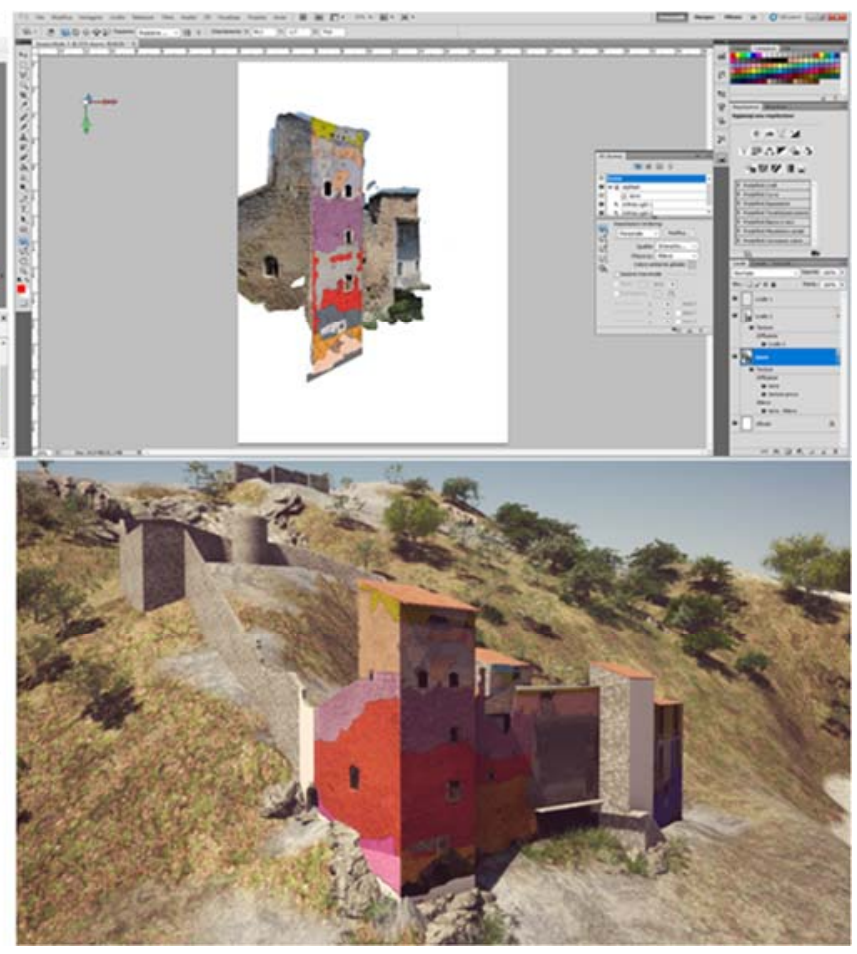

Figure 2: Stratigraphic analysis made on the three-dimensional model and on the front of the castle and the stratigraphic analysis imported into the virtual environment (this last made by A. Cordisco)

\section{METHODOLOGY FOLLOWED: FROM ARCHAEOLOGICAL ANALYSIS TO THE HBIM FOR THE RESTORATION PROJECT}

The parametric model of the castle of Fossa was developed starting from the current state of its buildings through to the now well-established "Scan-to-Bim" procedure (Figure 3). The point cloud of the photogrammetric model has been indexed and imported into Revit and has formed the basis for manual modeling, not only of buildings, but also of damages resulting from the earthquake (Figure 4). The information derived from the archaeological analysis, together with the data about the volumes of the single masonry units, on the technical and stylistic characteristics and on the stratigraphic relationships between them, have oriented the experimentation towards a more detailed parametric model design.

With this aim all the USMs and coating layers that characterize the south-east corner tower have been precisely modeled. The choice fell on this building both for its construction complexity (it presents a base scarp and several masonry techniques coeval and clamped each to other) and for the stratifications that it presents. In fact, the architectural additions due to the elevations, the openings and reconnections in the walls, are signs that highlight a temporal evolution to be correlated to the different changes of intended use that the tower has undergone. These 
characteristics well reflect the needs of the research in the HBIM experimentation illustrated here.

The modeling was performed for some stratigraphic units using existing parametric objects, modifying their profiles and adding more details to the database. Instead for others, given the uniqueness of the elements, as widely documented for HBIM, by constructig ad hoc families.

In this phase of the research, in order to increase the models's level of detail, all the elements that make up the tower have been modeled, differentiating walls and single windows, elements that distinguish themselves from each other due to their handmade realization (Figure 5).

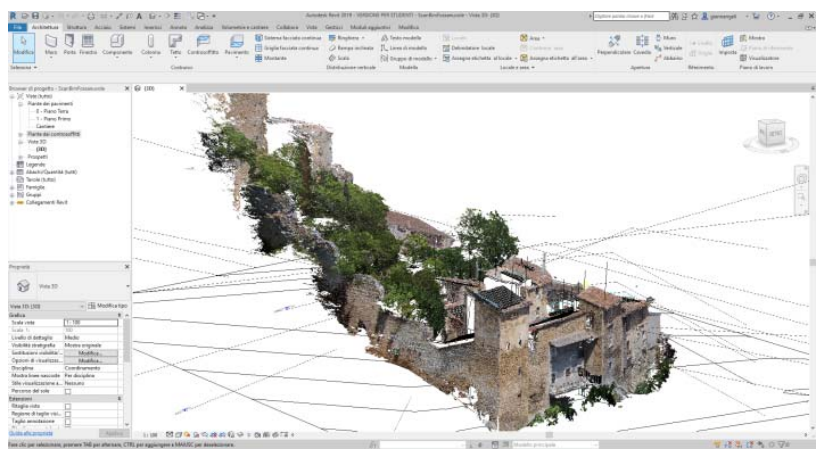

Figure 3: Screenshot of the point cloud of the castle obtained by the UAV survey imported in Revit.

\section{CONCLUSIONS AND FUTURE PERSPECTIVES}

The results of this multidisciplinary research, as well as ensuring accurate knowledge of the cultural heritage, at least in this first phase and preliminary to the drafting of the restoration project, allowed to build a HBIM model in line with the norms and proposals developed by the scientific community during the last years. At the current state of research it has been possible to realize, although with some difficulties typical of parametric modeling of historical buildings, a detailed model with much information, easily managed by the various professionals involved in many ways in the restoration project, and accessible through online platforms such as A360. For now, the parametric model obtained, as well as representing an important tool for coordinating the figures involved in the various phases of the restoration of the castle, has also allowed testing the BIM model for the management and conservation of the archaeological research data. This aspect is very important for archaeologists who work on historical buildings producing, by the stratigraphic analysis of the masonry, much information that needs to be correctly related to the graphic representation, possibly threedimensional, of the structure. For this reason, the experimentation illustrated here is part of a broader research field already started by the same team that for several years is looking for the most suitable digital tools for this purpose.

In this sense, the main experiments carried out by the team concern the integration of photogrammetric models with digital environments able to manage archaeological data such as 3DGIS (Trizio et al., 2019) or immersive models (Trizio et al., 2018a). For our team the BIM experimentation is still in its early stages, although the contribution shown here considerably increases those already proposed for the management of archaeological emergencies with low complexity (Trizio et al., 2018b) or stratigraphic data of buildings not damaged by the earthquake (Continenza et al., 2018; Marchetti et al., 2017).

Surely the complexity of the castle of Fossa, a fortified settlement whose articulated evolution is legible also through the different materials and construction techniques, is a good test for implementing the HBIM experimentation.

One of the future objectives of our team is testing the potentiality of the tool in the modeling and management of the entire architectural complex, naturally addressing some issues related to the purpose of the work, which in most cases determines the level of detail, which must still be enriched with the architectural project, of the analysis of the structures and of the energy one.

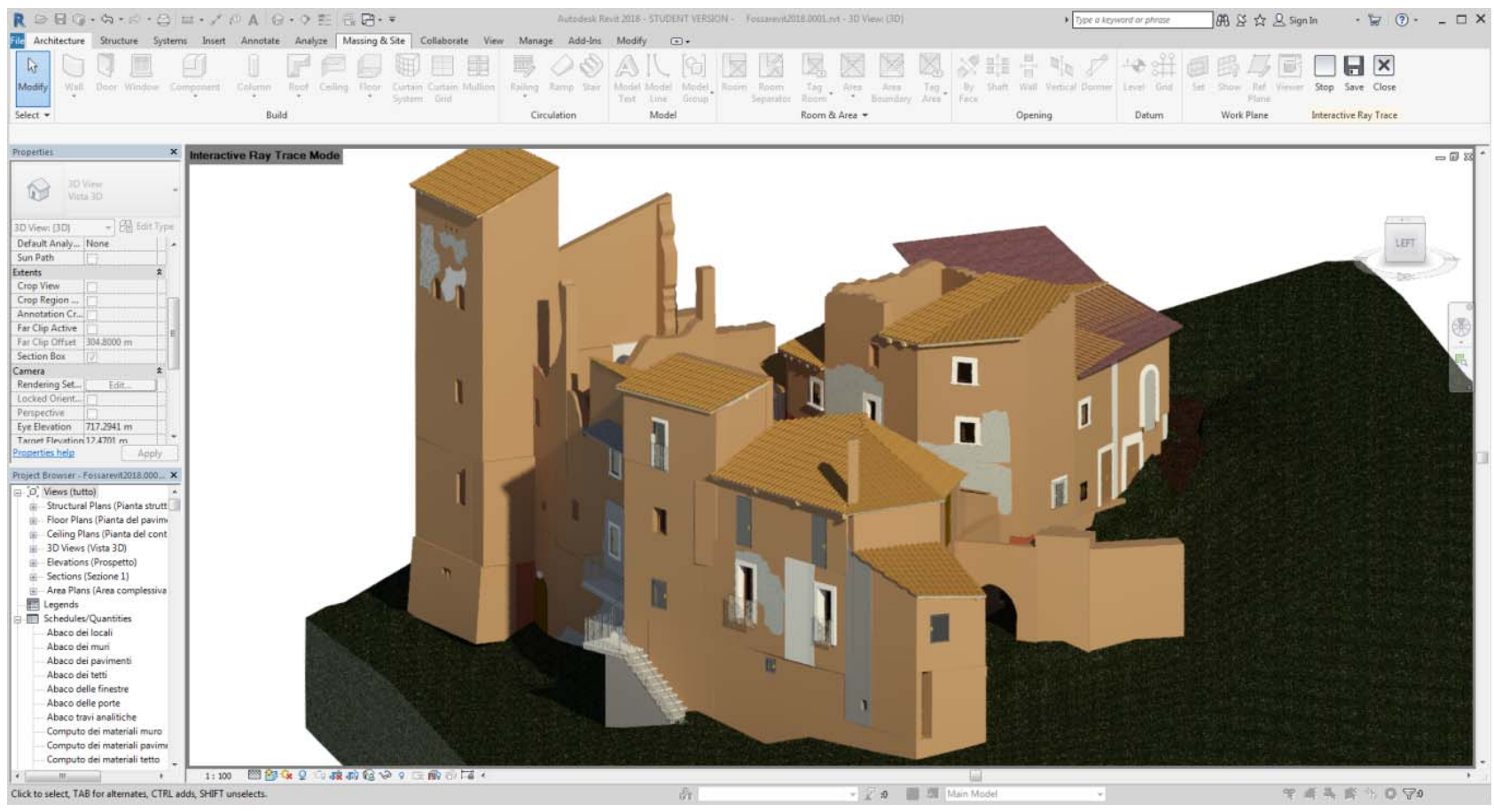

Figure 4: Screenshot of the Revit software with the parametric model of the Castle. 
Future interest is also to test the utility of the decomposed model and set up in individual USM for the planning of structural and energy interventions. This further experimentation could answer some questions that we asked ourselves during the realization of the model, such as how useful are typically archeological approaches to the development of the restoration project. In particular, we refer to the decomposition of the walls in minimal details using microstratigraphy or the habit of representing as a different unit the walls that are instead structurally linked to each other.

\section{ACKNOWLEDGEMENTS}

We want to thank the architect Roberta Boccabella for making the experimentation possible and all the professionals involved in the restoration project that have enriched the work presented here. Furthermore, we want to thank Professor Fabio Redi for the review of archaeological data, Dr. Gabriele Valentini for the financial support given to archaeological research.

\section{NOTE}

Although this contribution was jointly conceived by the authors, paragraphs 2 and 3 are to be attributed to Ilaria Trizio, while paragraphs 4 and 5 to Francesca Savini. Furthermore, Ilaria Trizio and Francesca Savini wrote paragraphs 1 and 6. Alessandro Giannangeli elaborated the three-dimensional photogrammetric model and Gabriele Petrucci the Revit model.

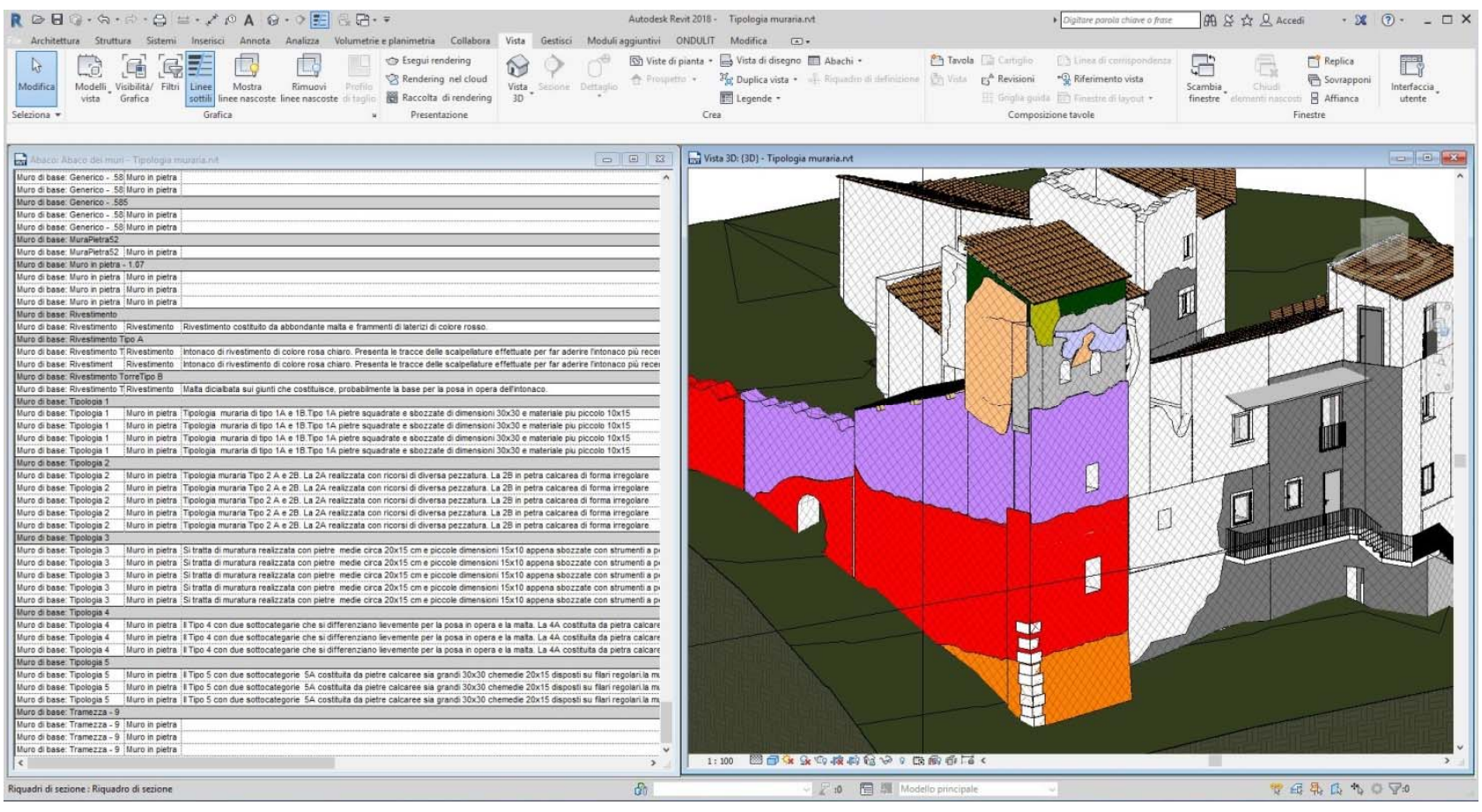

Figure 5: Screenshot of the Revit software with the archaeological analysis of the Castle.

\section{REFERENCES}

Acierno, M., Cursi, S., Simeone, D. and Fiorani, D. 2017. Architectural heritage knowledge modelling: An ontology-based framework for conservation process. Journal of Cultural Heritage, Vol. 24(2017), pp. 124-133.

Bianchini, C., Nicastro, S. 2018. The definition of the Level of Reliability: a contribution to the transparency of Historical-BIM processes. Dn. Building Information Modeling. Data \& Semantics, Vol. 2 (2018), pp.46-60.

Brogiolo, G.P and Cagnana, A. 2012. Archeologia dell'architettura. Metodi e interpretazioni. Collana Metodi e temi dell'archeologia medioevale, Firenze: all'insegna del giglio.

Brumana, R., Della Torre, S., Oreni, D., Previtali, M., Cantini, L., Barazzetti, L., Franchi, A. and Banfi, F. 2017. HBIM challenge among the paradigm of complexity, tools and preservation: the Basilica di Collemaggio 8 years after the earthquake (L'Aquila). ISPRS - International Archives of the
Photogrammetry, Remote Sensing and Spatial Information Sciences, Vol. 42(2W5), pp.97-104.

Brumana, R., Della Torre, S., Oreni, D., Cantini, L., Previtali, M., Barazzetti, L. and Banfi, F. 2018a. SCAN to HBIM-Post Earthquake Preservation: Informative Model as Sentinel at the Crossroads of Present, Past, and Future. In Ioannides M. et al. (Eds.), EuroMed 2018, LNCS 11196, pp. 39-51.

Brumana, R., Della Torre, S., Previtali, M., Barazzetti, L., Cantini, L., Oreni, D. and Banfi, F. 2018b. Generative HBIM modelling to embody complexity (LOD, LOG, LOA, LOI): surveying, preservation, site intervention - the Basilica di Collemaggio (L'Aquila). Applied Geomatics, Vol. 10(4), pp. 545-567.

Brusaporci, S., Trizio, I., Ruggeri, G., Maiezza, P., Tata, A. and Giannangeli, A. 2018. AHBIM per l'analisi stratigrafica dell'architettura storica. Restauro Archeologico, vol. 27(1), pp. 112-131. 
Buordin, S. 2006, I centri fortificati vestini...venti anni dopo. In Mattiocco E. (Ed.), Itinera Archaeologica. Contributi di archeologia abruzzese, pp. 9-36.

Carocci C.F., Campisi F. and Tranchina I. 2015. Earthquake and Enhancement: An Opportunity to Preserve the Medieval Castle of Fossa (L'Aquila, Italy). In Toniolo L., Boriani M. and Guidi G. (Eds.), Built Heritage: Monitoring Conservation Management. Cham: Springer International Publishing, pp. 237246.

Chiarizia, G., Latini, M.L. and Properzi. P. 2002. Atlante dei castelli d'Abruzzo. Repertorio sistematico delle fortificazioni, Pescara: Carsa.

Chiarizia, G. and Properzi, P. 1995. Abruzzo dei castelli. Gli insediamenti fortificati abruzzesi dagli italici all'unità d'Italia, Pescara: Carsa.

Clementi, A. 1977. Statuta Civitatis Aquile, Roma: Fonti per la Storia d'Italia.

Continenza, R., Redi, F., Savini, F., Tata, A. and Trizio, I. 2018. HBIM for the Archaeology of Standing Buildings: Case Study of the Church of San Cipriano in Castelvecchio Calvisio (L'Aquila, Italy). In Fogliaroni P., Ballatore A., Clementini E., (Eds.), Proceedings of Workshops and Posters at the 13th International Conference on Spatial Information Theory (COSIT 2017). COSIT 2017. Lecture Notes in Geoinformation and Cartography. Cham, Sw: Springer, pp. 315-323.

Cosentino, S., D'Ercole, V. and Mieli, G. 2001-2003. La necropoli di Fossa, voll. 1-4, Pescara: Carsa.

Della Torre, S. (Ed.) 2017. Built heritage information modelling management/ Modellazione e gestione e delle informazioni per il patrimonio edilizio esistente, sistema editoriale Ingenio, https:/www.ingenio-web.it/Sfogliabile/ReportageBHIMM2017 (Last accessed on December 2018).

Dore, C. and Murphy, M. 2012. Integration of HBIM and 3D GIS for Digital Heritage Modelling, Digital Documentation, 22-23 October, 2012 Edinburgh, Scotland.

Dore, C. and Murphy, M. 2018. Current state of the art Historic Building Information Modelling. The International Archives of the Photogrammetry, Remote Sensing and Spatial Information Sciences, Vol. XLII(2/W5), 201726th International CIPA Symposium 2017, 28 August - 01 September 2017, Ottawa, Canada, pp.185-192.

Fiorani, D., 2017. La modellazione della conoscenza nel restauro: uno sviluppo per il BHIMM. Problematiche generali e il casostudio di San Saba in Roma. In Della Torre, S., (Ed). Built heritage information modelling management/ Modellazione e gestione e delle informazioni per il patrimonio edilizio esistente, sistema editoriale Ingenio, https://www.ingenioweb.it/Sfogliabile/ReportageBHIMM2017 (Last accessed on December 2018).

Giovenazzi, V. M. 1773. Della città di Aveia nei Vestini ed altri luoghi di antica memoria, Roma.

Lo Turco, M. 2016. Minimum content of representation in BIM environment: towards a Future National Standard. In Empler T. (Ed.) 3D Modeling \& BIM: applications and possible future developments. DEI, Roma, 163-171.
Logothetis, S., Delinasiou, A. and Stylianidis, E. 2015. Building Information Modelling for cultural heritage: a review. ISPRS. Annals of the Photogrammetry, Remote Sensing and Spatial Information Sciences, Vol. II(5/W3), pp. 177-83.

López, F. J., Lerones, P. M., Llamas, J., Gómez- García-Bermejo, J. and Zalama, E. 2017. A Framework for Using Point Cloud Data of Heritage Buildings Toward Geometry Modeling in A BIM Context: A Case Study on Santa Maria La Real De Mave Church, International Journal of Architectural Heritage, Vol. 11(7), pp. 965-986.

López, F. J., Lerones, P. M., Llamas, J., Gómez-García-Bermejo, J. and Zalama, E. 2018. A Review of Heritage Building Information Modeling (H-BIM). Multimodal Technologies and Interact. Vol.2(2), 21.

Marchetti, A., Redi, F., Savini, F., Trizio, I. and Giannangeli, A. 2017. La chiesa di San Cipriano a Castelvecchio Calvisio (AQ) nella Baronia di Carapelle: documentazione speditiva e analisi stratigrafica 3D del manufatto. Archeologia dell'Architettura, Vol. XXII, pp. 239-253.

Martella, L. and Medin, A. M. 1988. Fossa e Ocre due impianti fortificati di dolina. In Rassegna di studi sul territorio, comunità montana Sirentina, pp. 32-56.

Mattiocco, E. 1989. Considerazioni sui centri fortificati preromani in Abruzzo. Bollettino della Deputazione Abruzzese di Storia Patria, Vol. LXXIX, pp. 453-509.

Murphy, M., McGovern, E. and Pavia, S. 2009. Historic building information modelling (HBIM). Structural Survey, Vol. 27(4), pp. 311-327.

Nicastro, S. 2016. L'applicazione del BIM come sistema informativo localizzato nel processo di conoscenza del Patrimonio Culturale. In Empler T. (Ed.), 3D Modeling \& BIM: applications and possible future developments. Roma: DEI, pp. 173-183.

Perogalli, C. 1975. Castelli dell'Abruzzo e del Molise, Milano: Gorlich.

PdG 2012. Piano di Ricostruzione di Fossa, (Last accessed on December 2018).

Pocobelli, D.P., Boehm, J., Bryan, P., Still, J. and Grau-Bové, J. 2018. BIM for heritage science: a review. Heritage Science, Vol 6(1), pp. 6-30.

Santangelo, E. 2002. Castelli e tesori d'arte della Media Valle dell'Aterno: Fossa, Ocre, San Demetrio ne' Vestini, Sant'Eusanio Forconese, Villa Sant'Angelo, Pescara: Carsa.

Scianna, A., Gaglio, G. F. and La Guardia, M. 2018. BIM Modelling of Ancient Buildings. In Ioannides M. et al.(Eds.), EuroMed 2018, LNCS 11196, pp. 344-355.

Trizio, I., Continenza, R. and Tata, A. 2017. Riscoperta del palazzo della famiglia Branconio in L'Aquila. Applicazioni BIM a un cantiere della ricostruzione aquilana. In Di Luggo A., et al. (Eds.), Territori e frontiere della rappresentazione, $39^{\circ}$ Convegno Internazionale dei Docenti delle Discipline della Rappresentazione, Roma: Gangemi, pp. 1659-1666. 
Trizio, I., Savini, F., Continenza, R., Giannangeli, A., Marchetti, A. and Redi, F. 2019. Photogrammetric survey and 3D GIS management of mesh in the integrated investigation of complex sites. The case study of the church of Santa Maria in Cesoni. In Inglese, C. and Ippolito A. (Eds.), Conservation, Restoration and Analysis of Architectural and Archaeological Heritage, IGI Global, pp. 48-80.

Trizio, I., Savini, F., De Gasperis, G. and Cordisco, A. 2018a. Siti perduti e inaccessibili: l'interpretazione del patrimonio attraverso applicazioni di realtà virtuale. In Salerno R. (Ed.), Rappresentazione materiale/immateriale. Drawing as (in) tangible representation. Atti del $40^{\circ}$ Convegno Internazionale dei docenti delle discipline della rappresentazione, XV Congresso UID - Milano 13-15 settembre 2018, Roma: Gangemi Editore, pp. 831-836.

Trizio, I., Savini, F. and Giannangeli, A. 2018b. The Building Information Modeling for the documentation of an archaeological site. Proceedings of the 2018 IEEE International Conference on Metrology for Archaeology and Cultural Heritage. IEEE, pp. 199-205.

UNI 11337-4-2017 - Edilizia e opere di ingegneria civile Gestione digitale dei processi informativi delle costruzioni - Parte 4: Evoluzione e sviluppo informativo di modelli, elaborati e oggetti, http://store.uni.com/catalogo/index.php/uni-11337-42017.html (Last accessed on December 2018).

Volk, R., Stengel, J. and Schultmann, F. 2014. Building Information Modelling (BIM) for existing buildings - Literature review and future needs. Automation in Construction, Vol. 38(2014), pp. 109-27. 